\title{
A Conceptual Framework for Antecedents and Consequence of Organizational Learning Capability
}

\author{
Azharuddin Hashim \\ Universiti Sains Islam Malaysia, Malaysia \\ dinbal2001@yahoo.com
}

\begin{abstract}
In extension of organizational learning study, the concept of organizational learning capability had emerged which stress on the importance of the facilitating factors for organizational learning or the organizational propensity to learn. Despite its recognized importance in the literature, little research has been devoted to the research centered on the related factors that could contribute to its development. Factors such as human resource management practices and leadership are identified as the strong predictor of organizational learning. There are also little attention has been given to relate organizational learning with organizational commitment, thus more research is required to analyze the relationships between organizational learning and issues concerning employees, such as organizational commitment. Thus this paper proposed the integration of human resource management practices, servant leadership, organizational learning capability and organizational commitment in a conceptual framework for future research.
\end{abstract}

Keywords: Organizational learning, organizational learning capability, human resource management practices, servant leadership, organizational commitment

\section{Introduction}

In the organizational context of the new millennium, it is clear that companies need to learn, and the organization's ability to learn is a key strategic capability to compete in modern markets (Santos-Vijande, López-Sánchez \& Trespalacios, 2012). The unpredictable competitive environment, accelerating changes in nature of work setting and fast changing of information technology have all shifted the rules of the business game. As a result, a strategic focus on learning has become a critical in helping organizations to sustain (Smith, 2012). Based on existing research, organizational learning field has aroused a great deal of interest, originating from the studies of Argyris \& Schon (1978). The main objective of organizational learning is to enhance an organization's core competence and create competitive advantages for success (Chau, 2008). Despite a cumulative tradition over the years, the organizational learning literature contains very little research on its implementation into practice (Taylor, Templeton \& Baker, 2010). Thus, to tackle the changes existing in the practices environment, organizations need to develop a series of specific capabilities and to regenerate their essential competences. From among these resources and capabilities that are specific to the firm, learning as one of the most important capabilities in the society of knowledge, stands out for its highly strategic role (Lloréns Montes, Ruiz Moreno \& García Morales, 2005). In the same line, implementing this organizational learning requires a series of characteristics allowing firms to develop the learning processes and, ultimately, become intelligent organizations. Only if they increased their capacity to learn would they be able to survive and adapt to the changing environment (Santos-Vijande et al., 2012). Consequently, organizational learning capability is considered as the organizational and managerial characteristics that facilitate the organizational learning process or allowing an organization to learn, plays an essential role in this process (Chiva, Alegre \& Lapiedra, 2007).

\section{Literature Review}

Organizational learning can be defined as the total combination of individual learning and the organizational capability to continuously enhance, the collective capacity to reflect, to learn how to learn, to unlearn old ways of doing things and abandon old habits (Senge, Roberts, Ross, Smith \& Kleiner, 1994). In furtherance, the concept of organizational learning capability (e.g. Dibella, Nevis \& Gould, 1996; Goh \& Richards, 1997; Hult \& Ferrell, 1997) seems to stress the importance of the facilitating factors for organizational learning or 
the organizational propensity to learn. Goh \& Richards (1997) defined it as the organizational and managerial characteristics or factors that facilitate the organizational learning process or allow an organization to learn. A firm's ability of to implement the appropriate management practices, structures, and procedures that facilitate and encourage learning processes is referred as organizational learning capability (Akgün, Keskin, Byrne \& Aren, 2007). Chau (2008) noted that the literature generally supports the use of strategic learning capability as the basis for measuring organizational learning. Such capability represents the capacity for organizational members to learn. Ussahawanitchakit (2008) argued that a capability to initiate, develop, enhance, and exploit learning in an organization is necessary in embracing the challenges of the organizational learning. Chiva et al. (2007) conceptualized organizational learning capability dimensions into five underlying dimensions namely; experimentation, risk taking, interaction with the external environment, dialogue and participative decision making. According to Chiva et al. (2007), these dimensions were considered as the most underlined facilitating factors in the literature. Although its importance prevailed in the literature, Rebelo \& Gomes (2011) however argued there are still lack of research on the related factors that could spur its development. Lähteenmäki, Toivonen, \& Mattila (2001)asserted that learning itself is seen as a prerequisite for the survival of today's organizations, and so it is quite understandable that there is a growing need to know more about the most favorable conditions for learning. According to Lähteenmäki et al. (2001), filling this knowledge gap is, however, not an easy job. Lopez (2006) asserted that it would be desirable to analyze human resource strategy along with other variables such as organizational structure and leadership. Since all the organizational factors are closely interlinked, the effectiveness of human resource management practices could be determined by the existence of a global approach affecting all areas of an organization.

Furthermore, the relationship between employees' belief regarding learning benefits and employees' commitment is as yet unclear. Chiva et al. (2007) noted that further research is needed to test the organizational learning capability in other contexts. At the employee level, more research is required to analyze the relationships between organizational learning capability and issues concerning employees, i.e. organizational commitment. Joo \& Park (2010) agreed that limited research has investigated the relationship between the two possible link of organizational learning and organizational commitment. It is important to consider the influence of organizational learning on commitment because the process of socialization involves learning which in turn is dependent on the availability of information within an organization (Morrison, 1993). Camps \& Rodríguez (2011) supported that there is a still lack of research on how it is connected to individual task performance although organizational learning capability has been connected to other individual behaviors. They believed this connection is justifiable through organizational commitment. Thus, the conceptual model proposed in this paper goes beyond examining the antecedents of organizational learning. In other words, the consequence and mediating role of organizational learning in influencing organizational commitment is another area to be investigated.

\section{The antecedents of organizational learning capability}

Human resource management practices: Although the developments in the field of human resource management practices are now well established in the literature, there is a need to focus on human resource management issues as firms are entering more dynamic international business markets (Lee, Ooi, Chong \& Tan, 2011; Budhwar \& Boyne, 2004). A review of literature on human resource management practices reveals extensive studies on organizational performance and effectiveness, but the association between human resource management practices and organizational learning has not been sufficiently covered in the literature (Kong, Chadee \& Raman, 2012; Theriou \& Chatzoglou, 2008). Jaw \& Liu (2003) posited that as invisible assets are embodied in people, policies regarding human resource management practices and activities are critical to organizational learning. Bhatnagar \& Sharma (2005), Perez Lopez, Montes Peon \& Vazquez Ordas (2005), Jerez-Gómez, Céspedes-Lorente \& Valle-Cabrera (2005) posited that human resource practices can be a fundamental tool in developing the organization's learning capability, which means that analyzing their possible influence opens a new field of study that has rarely been dealt with. Jerez-Gómez et al. (2005) argued that there is still debate about how managers can efficiently develop a learning capability in their firms. The learning schools tend to explain the role of human resource management practices as one concerned with the enhancement of an individual capacity to learn (Garavan, Gunnigle \& Morley, 2000). 
More recent, Martínez-León \& Martínez-García (2011) recommended human resource management practices as a future research to link with organizational learning. Theriou \& Chatzoglou (2008) pointed out that it is obvious from the literature presented, that best human resource management practices used by an organization have the potential to influence people's attitude towards learning. Khandekar \& Sharma (2005) found that the more specific human resource management practices exist in the organizations, the stronger the learning capability of the organization. Thus, organizational learning capability is strongly "bonded" on human factors which can, as already shown, be strongly shaped or manipulated by those human resource management practices that are usually described as "best human resource management practices". Khandekar \& Sharma (2005) point out if organizations are seeking competitive advantage through HR, they should design HR systems in ways that allow them to leverage and exploit knowledge-based resources and enable employees to use the knowledge for competitive edge. Thus, the discussion leads to:

Proposition 1: Human resource management practices have positive association with organizational learning capability.

Servant Leadership: A review of the literature on leadership reveals that there are many studies on measurement of leadership but the association of leadership and organizational learning capability has seldom been studied (Chau, 2008; Mirkamali, Thani \& Alami, 2011). Of the human resource-related aspects, this study shall concentrate on support leadership (Lloréns Montes et al., 2005). Berson, Nemanich, Waldman, Galvin \& Keller (2006), Zagoršek, Dimovski \& Škerlavaj (2009), Amy (2008) argued that leadership and organizational learning have limited systematic research directly linking leadership and learning and they remained disconnected fields. Although there is widespread presumption that leaders are the catalyst or powerful facilitators of organizational learning (Lakhani, 2005; Zagorzek et al., 2009), there is little research focusing on the specific practices through which leaders affect organizational learning (Lahteenmaki et al., 2001). As literatures prevailed, Vera \& Crossan (2004) were among the early research that systematically linked leadership and organizational learning. However, they focused mainly on leadership at the upper echelons of organizations. Extensive and large portion of leadership research state that transformational leadership seems to be strong prerequisite for organizational learning ( see Vera \& Crossan, 2004; Malik, Danish \& Munir, 2012; Mirkamali et al., 2011; Camps \& Rodríguez, 2011; Zagoršek et al., 2009). However, as one of the notable researcher in transformational leadership style, Bass (1999) proposed that since most organizations need to keep learning at all levels in order to adapt to their changing environments, servant leadership should be of interest for today's organizational leaders for it enables and empowers people to learn and grow. Likewise, Senge (1990) emphasized the importance of the concept by stating that he believes the essay by Robert Greenleaf (1970), titled The Servant as Leader, as the most useful statement on leadership in the last 20 years. This claim by such an influential author begged more empirical study of the emerging theory of servant leadership (Drury, 2004).

Covey (2002) believed servant leadership requires humility of character and core competency built around new skills. Covey (2002) recommended a servant leader approach view that "you don't just serve; you do it in a way that makes them independent of you, and capable and desirous of serving other people" (p. 31). Mittal \& Dorfman (2012) asserted that even though servant leadership is a relatively new construct in the leadership literature appearing in the writings of Greenleaf (1970), it has its origin far earlier, in religion and philosophy. Current models of servant leadership are anchored in the human drive to bond with others and contribute to the betterment of the society. In Islam ("the leader of a people is their servant") and other world religions have long embraced the philosophy of servant leadership. Melchar \& Bosco (2010) posited that the servant leadership research is being criticized due to the lack in published, well designed, empirical research. Thus, its lead to the lack of acceptance of the theory and limitation to generate the widespread acceptance (Russell \& Stone, 2002). Thus, the discussion leads to:

Proposition 2: Servant leadership has positive association with organizational learning capability.

\section{The consequences of organizational learning capability}

Organizational commitment: Retaining valued and committed employee to the organization is a top priority for many contemporary organizations today (Neininger, Lehmann-Willenbrock, Kauffeld \& Henschel, 2010) and its importance are encompasses at all levels within an organization (Hausknecht, Rodda \& Howard, 2009). Therefore in order to be able to learn better and faster from their successes or failures within 
internal or external of organizations, it is necessary to extend their learning capability and competencies to such that will increase the organizational commitment (Zollo \& Winter, 2002). Organizations are not disappearing; they may be becoming leaner, but they must maintain a core of people who 'are' the organization. As organization becomes smaller and jobs become more flexible, those who remain in the organization become even more important. Once the "fit" is gone, the remaining employees represent the "heart, brain and muscle" of the organization (Meyer \& Allen, 1997). Thus, over the recent years, many firms try to attract, develop and retain people with business required talent in pursue to become an employer of choice due to the business stiff competition (Joo \& McLean, 2006). In the era of rapid change and to keep pace with globalization, securing commitment and retaining skilled employees have become key challenges for an organization to gain competitive advantage (Joo \& Park, 2010; Suman \& Srivastava, 2012; Kalyar, Rafi \& Ahmad, 2012). The cost associated with losing key employees, or retaining less productive ones in depressed economic conditions, has long been recognized by organizational leaders. Thus, undesired turnover and underproductive employees have a negative impact on firm profitability (Doh, Smith, Stumpf \& Tymon, 2011).

Organizational learning researchers have traditionally examined organizational commitment as a focused sub attitudinal facet where commitment is seen as a necessary pre requisite for successful change management (Massingham \& Diment, 2009). This approach typically characterizes organizational commitment as buy in and attitudes are measured in terms of willingness to accept a specific change initiative. Garvin (1993) posited organizational learning as one of the key contextual components to enhance organizational commitment. Garvin defined organizational learning as to an organization skilled to create, acquire and transfer knowledge, and at modifying its behavior to reflect new knowledge and insight. More research about the impact of organizational learning on employees' organization commitment is recommended. Many researchers linked organizational learning and organizational performance (Khandekar \& Sharma, 2005; Michna, 2009), but little attention has been given to relate organizational learning with organizational commitment, thus more research is required to analyze the relationships be-tween organizational learning and issues concerning employees, such as organizational commitment (Chiva et al., 2007). Thus, the discussion leads to:

Proposition 3: organizational learning capability has positive association with organizational commitment.

Organizational learning capability as mediating variable: The existing management and leadership research has demonstrated the effects of human resource management practices, leadership, and organizational learning on organizational commitment separately. However, researchers have not yet measured the relationship between human resource management practices, leadership style on organizational commitment as mediated by organizational learning capability. Guchait \& Cho (2010) stressed that although previous studies have suggested, e.g., human resource management practices are related to organizational commitment, some scholars have found that these relations are not necessarily direct. Meyer \& Smith (2000) posited that the assumption of a direct influence of the implementation of a particular human resource management practices on employees' organizational commitment cannot be made. Theriou \& Chatzoglou (2008) added that there is still little understanding of the mechanisms through which human resource management practices influence organizational effectiveness. Therefore, the question of "how" best human resource management practices lead to organizational performance needs to be answered and the exact mechanics that play an important role must be identified. Tremblay, Cloutier, Simard, Chênevert \& Vandenberghe (2010) suggested that an exchange mechanism must intervene upstream for human resource management practices in influencing organizational commitment. Thus, the discussion leads to:

Proposition 4: Organizational learning capability mediates the relationship between human resource management practices, servant leadership and organizational commitment.

Based on the above statements and recognizing that only a few studies centered on its determinants have been carried out, the aim of this research is to examine the human resource management practices and servant leadership that could act as potential determining or facilitating factors of organizational learning capability. Further research is also aimed at examining organizational commitment as the consequence variable of organizational learning capability. Beside, from the preliminary review of the literature, to the extent of author's knowledge, there appears to be no research that examined the relationship or integration 
among human resource management practices, servant leadership and organizational commitment, mediated by organizational learning capability in the organizational learning literature.

Conceptual Framework: The significant importance of organizational learning has received significant attention among researchers and practitioners but there is a few cumulative and empirical research which leads to the development of the proposed conceptual model drawing from previous studies. Thus, based on the research gaps and argument discussed in this paper, human resource management practices (HRM) and servant leadership (SL) variables are postulated as antecedents of organizational learning capability (OLC), and the impact on organizational learning capability on the organizational commitment (OC) as in Figure 1:

Figure 1: Conceptual framework

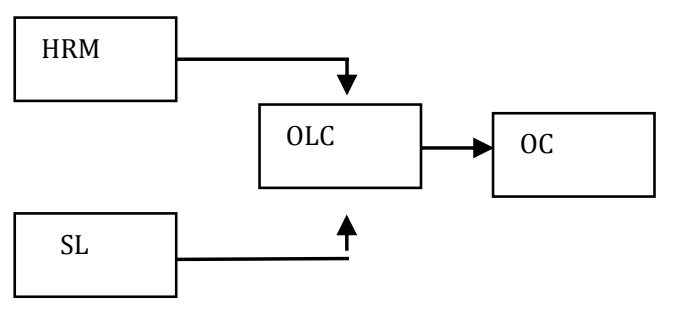

\section{Conclusion}

This study extracted examines the issue of organizational learning, which has the potential to impacts on employees' organizational commitment. It is proposed that organizational learning has certain impacts on organizational commitment, which in turn will affect employees' turnover intention. Organizational learning will help the organization to enhance employees' learning capability and it will make the employee have a strong engagement and intention to stay, and become closely attached to the organization. Thus, employee commitment contributes to the fulfillment of overall organization performance. Previous researchers demonstrate that organizational learning is a source of competitive advantage, it offers an alternative paradigm by which systems can change, thus permitting us to redefine the economy and society. In an era of rapid changes in the business world, organizational learning will allow companies to remain flexible, adaptable and innovative, thereby gaining a lasting advantage over their competitors. In Malaysian context, this study could provide initial insight into the nature of the said relationship. It could provide some guidelines for managers to understand the value of learning that could lead to implementation of more effective policies for improving employees' commitment at work.

\section{References}

Akgün, A. E., Keskin, H., Byrne, J. C. \& Aren, S. (2007). Emotional and learning capability and their impact on product innovativeness and firm performance. Technovation, 27(9), 501-513.

Argyris, C. \& Schon, D. (1978). Organizational learning: A theory of action perspective. Reading: AddisonWesley.

Amy, A. H. (2008). Leaders as facilitators of individual and organizational learning. Leadership \& Organization Development Journal, 29(3), 212-234.

Bass, B. M. (1999). Two Decades of Research and Development in Transformational Leadership. European Journal of Work and Organizational Psychology, 8(1), 9-32.

Berson, Y., Nemanich, L. A., Waldman, D. A., Galvin, B. M. \& Keller, R. T. (2006). Leadership and organizational learning: A multiple levels perspective. The Leadership Quarterly, 17(6), 577-594.

Bhatnagar, J. \& Sharma, A. (2005). The Indian perspective of strategic HR roles and organizational learning capability. The International Journal of Human Resource Management, 16(9), 1711-1739.

Budhwar, P. \& Boyne, G. (2004). Human Resource Management in the Indian Public and Private Sectors: An Empirical Comparison. The International Journal of Human Resource Management, 15(2), 346-70.

Camps, J. \& Rodríguez, H. (2011). Transformational leadership, learning, and employability: Effects on performance among faculty members. Personnel Review, 40(4), 423-442.

Chau, S. L. (2008). Organizational learning (Analysis). International Journal of Strategic Management, 8(1). 
Chiva, R., Alegre, J. \& Lapiedra, R. (2007). Measuring organisational learning capability among the workforce. International Journal of Manpower, 28(3/4), 224-242.

Covey, S. R. (2002). Servant-leadership and community leader-ship in the twenty-first century. In L.C. Spears \& M. Lawrence (Eds.), Focus on leadership: servant-leadership for the 21st century (27-33). New York: John Wiley \& Sons.

Dibella, A. J., Nevis, E. C. \& Gould, J. M. (1996). Understanding organizational learning capability.Journal of Management Studies, 33(3), 361-379.

Doh, J. P., Smith, R. R., Stumpf S. A. \& Tymon-Jr, W. G. (2011). Pride and professionals: Retaining talent in emerging economies. Journal of Business Strategy, 32(5), 35-42.

Drury, S. (2004). Employee perceptions of servant leadership: Comparisons by level and with job satisfaction and organizational commitment. Virginia Beach: Regent University.

Garavan, T. N., Gunnigle, P. \& Morley, M. (2000). Contemporary HRD research: a triarchy oftheoretical perspectives and their prescriptions for HRD. Journal of European Industrial Training, 24(2/3/4), 65 $-93$.

Garvin, D. A. (1993). Building a learning organization. Harvard Business Review, 71(4), 78-91.

Goh, S. \& Richards, G. (1997). Benchmarking the Learning Capability of Organizations. European Management Journal, 15(5), 575-583.

Greenleaf, R. K. (1970). The servant as leader. Indianapolis, ST: The Robert K. Greenleaf Center.

Guchait, P. \& Cho, S. (2010). The impact of human resource management practices on intention to leave of employees in the service industry in India: the mediating role of organizational commitment. The International Journal of Human Resource Management, 21(8), 1228-1247.

Hausknecht, J. P., Rodda, J. \& Howard, M. J. (2009). Targeted employee retention: Performance-based and jobrelated differences in reported reasons for staying. Human Resource Management, 48(2), 269-288.

Hult, G. T. M. \& Ferrell, O. C. (1997). Global Organizational Learning Capacity in Purchasing: Construct and Measurement. Journal of Business Research, 2963(96), 97-111.

Jaw, B. S. \& Liu, W. (2003). Promoting organizational learning and self-renewal in Taiwanese companies: The role of HRM. Human Resource Management, 42(3), 223-241.

Jerez-Gómez, P., Céspedes-Lorente, J. \& Valle-Cabrera, R. (2005). Organizational learning capability: a proposal of measurement. Journal of Business Research, 58(6), 715-725.

Joo, B. \& Park, S. (2010). Career satisfaction, organizational commitment, and turnover intention: The effects of goal orientation, organizational learning culture and develop-mental feedback. Leadership \& Organization Development Journal, 31(6), 482-500.

Joo, B. \& McLean, G. N. (2006). Best employer studies: A conceptual model from a literature review and a case study. Human Resource Development Review, 2(1), 228-57.

Kalyar, M. N., Rafi, N. \& Ahmad, B. (2012). Organizational learning and organizational commitment: A correlational study in manufacturing context. African Journal of Business Management, 6(9), 33493355.

Khandekar, A. \& Sharma, A. (2005). Organizational learning in Indian organizations: a strategic HRM perspective. Journal of Small Business and Enterprise Development, 12(2), 211-226.

Kong, E., Chadee, D. \& Raman, R. (2012). Managing Indian IT professionals for global competitiveness: the role of human resource practices in developing knowledge and learning capabilities for innovation. Knowledge Management Research \& Practice, 1(12).

Lähteenmäki, S., Toivonen, J. \& Mattila, M. (2001). Critical Aspects of Organizational Learning Research and Proposals for Its Measurement. British Journal of Management, 12, 113-129.

Lakhani, M. A. (2005). Relational linkages between visionary leadership and organizational learning across the United States, Malaysia and India. Phoenix: University of Phoenix.

Lee, V. H, Ooi, K. B, Chong, A. Y. \& Tan, B. I. (2011). HRM practices and organizational learning: a critical review and research agenda. International Journal of Innovation and Learning, 10(4).

Lloréns Montes, F. J., Ruiz Moreno, A. \& García Morales, V. (2005). Influence of support leadership and teamwork cohesion on organizational learning, innovation and performance: an empirical examination. Technovation, 25(10), 1159-1172.

Lopez, S. P. (2006). Human Resource Management as a Determining Factor in Organizational Learning. Management Learning, 37(2), 215-239.

Malik, M. E., Danish, R. Q. \& Munir, Y. (2012). The Role of Transformational Leadership and Leader's Emotional Quotient in Organizational Learning. World Applied Sciences Journal, 16(6), 814-818. 
Martínez-León, I. M. \& Martínez-García, J. A. (2011). The influence of organizational structure on organizational learning. International Journal of Manpower, 32(5/6), 537-566.

Massingham, P. \& Diment, K. (2009). Organizational commitment, knowledge management interventions, and learning organization capacity. The Learning Organization, 16(2), 122-142.

Melchar, D. E. \& Bosco, S. M. (2010). Achieving High Organization Performance through Servant Leadership. The Journal of Business Inquiry, 9(1), 74-88.

Meyer, J. P. \& Allen, N. J. (1997). Commitment in the workplace: Theory, research, and application. Thousand Oaks, CA: Sage.

Meyer, J. P. \& Smith, C. A. (2000). HRM Practices and Organizational Commitment: Test of a Mediation Model. Canadian Journal of Administrative Sciences, 17(4), 319-331.

Michna, A. (2009). The relationship between organizational learning and SME performance in Poland. Journal of European Industrial Training, 33(4), 356-370.

Mirkamali, S. M., Thani, F. N. \& Alami, F. (2011). Examining the Role of Transformational Leadership and Job Satisfaction in the Organizational Learning of an Automotive Manufacturing Company. Procedia Social and Behavioral Sciences, 29, 139-148.

Mittal, R. \& Dorfman, P. W. (2012). Servant leadership across cultures. Journal of World Business, 47(4), 555570.

Morrison, E. W. (1993). Newcomer information seeking: Exploring types, modes, sources, and outcomes. Academy of Management Journal, 36(3), 557-589.

Neininger, A., Lehmann-Willenbrock, N., Kauffeld, S. \& Henschel, A. (2010). Effects of team and organizational commitment - A longitudinal study. Journal of Vocational Behavior, 76(3), 567-579.

Perez Lopez, S., Montes Peon, J. M. \& Vazquez Ordas, C. J. (2005). Human Resource Practices, Organizational Learning and Business Performance. Human Resource Development International, 8(2), 147-164.

Rebelo, T. M. \& Gomes, A. D. (2011). Conditioning factors of an organizational learning culture. Journal of Workplace Learning, 23(3), 173-194.

Russell, R. F. \& Stone, A. G. (2002). A review of servant leadership attributes : developing a practical model.Leadership and Organization Development Journal, 23(3), 145-157.

Santos-Vijande, M. L., López-Sánchez, J. Á. \& Trespalacios, J. A. (2012). How organizational learning affects a firm's flexibility, competitive strategy, and performance. Journal of Business Research, 65(8), 10791089.

Senge, P. (1990). Building leaming organizations. Sloan Management Review, 3, 7-23.

Senge, P. M., Roberts, C., Ross, R. B., Smith, B. J. \& Kleiner, A. (1994). The fifth discipline fieldbook, Doubleday, New York, NY.

Smith, P. A. C. (2012). The importance of organizational learning for organizational sustainability. The Learning Organization, 19(1), 4-10.

Suman, S. \& Srivastava, A. K. (2012). Antecedents of Organisational Commitment across Hierarchical Levels. Psychology \& Developing Societies, 24(1), 61-83.

Taylor, G. S., Templeton, G. F. \& Baker, L. T. (2010). Factors Influencing the Success of Organizational Learning Implementation: A Policy Facet Perspective. International Journal of Management Reviews, 12(4), 353-364.

Theriou, G. N. \& Chatzoglou, P. D. (2008). Enhancing performance through best HRM practices, organizational learning and knowledge management: A conceptual framework. European Business Review, 20(3), 185-207.

Tremblay, M., Cloutier, J., Simard, G., Chênevert, D. \& Vandenberghe, C. (2010). The role of HRM practices, procedural justice, organizational support and trust in organizational commitment and in-role and extra-role performance. The International Journal of Human Resource Management, 21(3), 405-433.

Vera, D. \& Crossan, M. (2004). Strategic leadership and organizational learning. The Academy of Management Review, 29(2), 222-240.

Ussahawanitchakit, P. (2008). Organizational Learning Capability, Organizational Commitment, And Organizational Effectiveness: An Empirical Study Of Thai Accounting Firms. International Journal of Business Strategy, 8(3).

Zagoršek, H., Dimovski, V. \& Škerlavaj, M. (2009). Transactional and transformational leadership impacts on organizational learning. Journal for East European Management Studies 144-166.

Zollo, M. \& Winter, S. G. (2002). Deliberate Learning and the Evolution of Dynamic Capabilities. Organization Science, 13(3), 339-351. 